Djurdjica Vukajlović ${ }^{1}$

Miodrag Brzaković

University Business Academy in Novi Sad,

Faculty of Applied Management,

Economics and Finance, Belgrade

Nikola Ćurčić ${ }^{3}$

University Union- Nikola Tesla,

Faculty of Management, Sremski Karlovci
SCIENTIFIC REVIEW ARTICLE doi:10.5937/ekonomika1603047V

Received: July 29, 2016

Accepted: Septembar 9, 2016

\title{
ASSESSMENT OF EMPLOYEES COMPETENCES CARRIED OUT BY DIFFERENT MANAGEMENT LEVELS
}

The success of any organization depends on the human resources, their knowledge and skills, and their competencies. Competenceis are developed for the needs of business and the organization in which the individual is working. The aim of the study was to determine how the managers of different levels judge competencies of their employees. The results showed that managers value the most employees eager to learn something new in order to improve knowledge and skills, while the least valued competence is planning and verification of the task before relalization in all of its stages. The results also showed that managers of different levels variously estimate certain competence of their employees.

Key words: competence, human resources, employees, management

JEL classification: M 500, M 540

\section{ОЦЕНА КОМПЕТЕНЦИ ЗАПОСЛЕНИХ ОД СТРАНЕ РАЗЛИЧИТИХ МЕНАЏМЕНТ НИВОА}

\begin{abstract}
Апстракт
Успех сваке организације зависи од људских ресурса, њихових знаға ивештина, односно од юихових компетенци. Компетение се развијају за потребе посла и организације у којој индивидуа ради. Циљ рада је био да се утврди како менацери различитог нивоа оцењују компетенце запослених. Резултати су показали да менацери највише иене када запослени жели да научи нешто ново како би унапредио знана и вештине, док је најмање вреднована компетенияа запослених планирање и провере задатка пре извршена у свим фазама обављања задатка. Резултати су такође показали да меначери различитих нивоа различито ичене одређене компетенце код запослених.
\end{abstract}

Кључне речи: компетенце, људски ресурси, запослени, менацемент

\footnotetext{
${ }^{1}$ vukajlovicdj@com

${ }^{2}$ miodrag.brzakovic@mef.edu.rs

${ }^{3}$ nikolavcurcic@yahoo.com
} 


\section{Introduction}

For an organizations operating in the ever-changing environment it is extremely important to quickly and effectively implement new business strategies. Employees in an organization are the resource that start changes directing other resources and environment in the direction of initiation and adjustment to the changes. In this sense, competence can be used as a powerful communications tool that transforms vision into people's behavior in a way that they understand and implement (Sanchez \& Levine, 2009). For organizations it is very difficult to determine what are the competence of employees that will help managers to successfully achieve the goals of the organization. The ability to assess the compentence and determine the dampener of competency skills it is extremely difficult, since it enables organizations to manage better the work of individual and group. Determining which competencies are relevant to different managerial functions, but also for the employees, is crucial for the development and promotion of developmental programs (Seate, Pooe \& Chinomona, 2016). Looking through the history of the practice and applied research, the concept of competence has primarily been directed at managers, followed by the growth of the managerial group. In more recent practice in many successful organizations is noticable orientation on defining competencies in recruitment, rather than the traditional approach based on evaluation of knowledge, abilities, skills, derived from analysis of the work (Vujić, 2015). Every business and every job has different requirements and different characteristics, so for this reason we separate different competence of employees that need to match the requirements of the work to be performed, and managers are the ones who manage the organization and who select and lead employees to achieveing business objectives.

\section{The specificity of human resources}

Success of the organization depends on the quality of resources available to orit. If human resources are seen as a factor of production (in a broad sense), that can be their specificity in relation to other resources. Unlike other resources that are mostly easy to describe and keep "under control", with stable characteristics and (relatively) predictable, human resources are characterized by the following (Aksentijević, Avakumović \& Jelić, 2010): complex to manage, complex to maintain, requires considerable attention to achieve effectiveness, they are slowly made, but fastly destroied, they are highly specific (at the same time there is a surplus and shortage of human resources in most organizations). Human resources for its specific characteristics are extremely difficult to be managed, but on the other side on their quality depends the success of a business of an organization, which depends on three sets of expectations (Kermally, 2004): expectations of the organization, expectations of employees and the expectations of the customers. In modern conditions of business leadership and knowledge are becoming the most valuable resource of the organization (Stojković, Davidovac \& Stojmirović, 2014), and that is why leadership characteristics need to be mastered by the manager in order to lead employees to behavior, values, attitudes, characteristics and skills that are essential for achieving the goals of the organization. 
When one person becomes part of the organization, its abilites develop through the effective exchange of different development efforts, such as training and periodic evaluation of the performance (Bartol \& Martin, 1994) administered by managers of different levels. To learn new skills and develop expertise and knowledge, managers and employees must make a particular effort to put the development of employees at or the top of the priority list (Nelson \& Economy, 2005).

Organization has at its desposal human resources from internal and external sources. The internal are all employees in the organization, but it should be took into account the fact that this is a very volatile category that depends on hiring new people, retired employees, layoffs, and so on, we should bear in mind that an employee in the course of their employment improves knowledge and skills (Bogićević, 2004). Labour productivity depends on many external, internal (in relation to the organization) and psychological factors that can at the same time affect the work motivation. Certain conditions of working environment, such as management style, work organization, interpersonal relations and many others, can shape the relationship between the particular work motivation and labour productivity (Micić, 2015).

Any meaningful activity has to be managed, and each management seeks a goal which is why it is necessary certain resources to be provided. The goal of human resources management is achieving success through employees, achieving the following goals: organizational, functional, social and personal (Šušnjar \& Zimanji, 2006).

\section{Competency of employees}

The very idea of competence has the meaning of juristiction, abilities, skills, expertise, responsibilities. Several authors in the field of human resources management (Wilkinson \& Marchington, 2005) considere and that the term "competency" consider representation of different content, starting with the juristiction, personal characteristics, attitudes, values, interpersonal skills, through professional skills and knowledge.

Competence represent the capacity of individuals to develop their behaviour, adequate to the needs of the business, which are guided by the parameters of the organizational environment to achieve the desired result. Competence is a mix of knowledge, skills and attitudes (Krishnaveni, 2013). HR needs to help all other functions of the organization and it has constantly to work on improving its own systems, processes, practices and skills, by providing relevant internal and external training and expertise (Deb, 2006). In this way competence of employees promotes and harmonise with the requirements of the organisation.

Competence includes a number of procedures, skills and capabilities, attitudes, beliefs and values, preferences and personal characteristics, selfperception and motivation which make the numerous requirements of business effectively fulfilled (Rubin et al., 2007). Competence that an individual possesses can be developed through formal training or experience. Those develop through education are considered more general competence, given that they are usable in multiple organizations through a variety of jobs. Competence generated through experience are more specialized and often associated with the organization in which they have developed and represent value to the organization (Becker, 1983). Through specifying competence in this sense, we 
need to approach in terms of factors that directly or indirectly affect the job performance or individual.

Competence include a specific set of knowledge that traditionally can be seen as: computing, communications, economics, mathematics, science, physic, quantitative reasoning, social sciences etc. Eight competences are important according to EU standards (Praštalo, 2010): communication in the mother tongue, communication in foreign languages, mathematical competence and basic science and technology, digital competence, learning to learn, social and civic competence, sense of initiative and entrepreneurship, and cultural enlightenment of expression in the field of culture. All competences listed are considered to be equally important, because each of them contributes to creating a successful life of the individual in society. Competence can refer to the behavior of a particular individual, how he behaves and responds to the environment during the execution of their business (Robotham \& Jubb, 1996).

It is clear that apart from having the basic skills necessary to perform a specific task, it is needes a generic and transferable (transversal) competence that will provide all of the individual set of skills, knowledge and attitudes which are related to individual situations, in order not to feel inferior in these situations. The ability to use skills in a given context is called application or use. Use one skill that is acquired through education or training is the application of skills of human knowledge. Potential employers are interested in what someone does and how well he does it. However, they are particularly interested in whether someone can apply the knowledge and skills acquired through education at work.

Numerous studies dealt with the managers of different levels and their respective roles in human resources management (Gilbert, Winne, \& Sels, 2015), as well as a score of management made by employees (Sanders \& Yang, 2015). In different organizations and in various countries of the world representation of competences that are considered most important is different. Studies have shown (Department of Education, Science and Training, 2002) the general skills needed for employment may include the following: communication skills, capacity for teamwork, ability to solve problems, take the initiative and manage, the ability for planning and organization skills, self-direction, capacity for learning, the use of modern technology. Personal attributes that contribute to employment can be seen as: loyalty, dedication, honesty, enthusiasm, reliability, personal presentation, rational reasoning, self-esteem, sense of humor, balanced attitude towards business and private life, the ability to work under pressure, motivation, adaptability. Competence that exhibit either through general abilities and personal qualities are something that managers need to recognize in the employee as a condition for achieving specific results in work.

\section{Research methodology}

The research was conducted as an empirical study of transversal character (intersection). The pattern was random, with the condition that the respondent has at least one employee that manages. It comprised around 300 managers from the territory of Serbia. Questionnaires are sent electronically, and it were 290 valid returned questionnaires, which are taken into account when processing data. The aim of this study 
was to determine what are the employees competences that managers most prices, as well as to determine whether there is a difference in scores of competences, made by managers of different levels.

In the sample there were 106 managers $(36.6 \%)$ that manage people who also have people to manage (top management), $154(53,1 \%)$ of managers consisted of the medium level management, while $30(10.3 \%)$ were of those who are engaged in processes (owners of small businesses who are governed by themselves and participate in processes).

The aim of this study is to determine which competence of the employees managers most value. It was taken into account 10 variables that subjects assessed with the grades from 1 to 5 where 1 is the lowest rating (meaningless competence), and 5 the highest rating (key competence). Competence of employees who have been questioned by the selected codes of $\mathrm{P} 1-\mathrm{P} 10$, is represented below:

P1 - Doesn't ask for confirmation or clear instructions for each task performed. Understand the broader context of work and can independently make decisions in the scope of their own tasks.

P2 - Wants to learn something new in order to improve knowledge and skills which will facilitate current business.

P3 - Paying a lot of attention to the documentation that is part of the job, and an appreciation of his procedure is primarily in the process of work.

P4 - Always approaches the work with a lot of energy.

P5 - Gain enthusiasm of others forits ideas and plans.

P6 - Does not resist changes through which an organization goes, recognizes it as a positive influence to achieve the organization's business.

P7 - Regardless of the daily tasks and nature of the work, interpersonal relationship is important to him and takes care of the communication with colleagues, nurturing quality of interpersonal relationships.

P8 - Recognises that there are less important tasks that can wait for primary job or higher/emergency task to be done.

P9 - He/she doesn't execute any task without the careful planning and verification of the different stages of the completion of the task.

P10 - When he/she sees the advantage of its ideas and projects, advocates them with quality arguments in order for others to accept suggestion.

Managerial levels are divided as following, and for better viewing they are indicated as following:

- Manager/Executive (top management)-TM

- Middle management (middle-level managers, supervisors)-SM

- Line/operational management (heads of departments, managers, etc.)-LM

In table 1. in a column Mean are central values for each variable of observed depending on the internal management level respondents, as well as the overall averages. It shows that managers best assessed employees who want something new to learn to improve knowledge and skills with an average score of 3.87 (P2). The least valued (average grades 3.59) competence of employees is related to the planning and execution phases of the evaluation before the completion of the certain task (P9). 
Table 1. Descriptive statistics assessment of employees competences

\begin{tabular}{|c|c|c|c|c|c|}
\hline & & $\mathbf{N}$ & Mean & $\begin{array}{c}\text { Std. } \\
\text { Deviation }\end{array}$ & $\begin{array}{c}\text { Std. } \\
\text { Error }\end{array}$ \\
\hline & & $\begin{array}{l}\text { Lower } \\
\text { Bound }\end{array}$ & $\begin{array}{l}\text { Upper } \\
\text { Bound }\end{array}$ & Lower Bound & $\begin{array}{l}\text { Upper } \\
\text { Bound }\end{array}$ \\
\hline & TM - Top management & 76 & 3.58 & 1.278 & .147 \\
\hline & SM - Middle management & 174 & 3.78 & 1.015 & .077 \\
\hline PI & LM - Line management & 40 & 4.23 & .800 & .127 \\
\hline & Total & 290 & 3.79 & 1.079 & .063 \\
\hline & TM - Top management & 76 & 3.95 & .831 & .095 \\
\hline & SM - Middle management & 174 & 3.86 & .849 & .064 \\
\hline $\mathrm{P} 2$ & LM - Line management & 40 & 3.75 & .707 & .112 \\
\hline & Total & 290 & 3.87 & .826 & .048 \\
\hline & TM - Top management & 76 & 3.24 & 1.355 & .155 \\
\hline P3 & SM - Middle management & 174 & 3.57 & 1.038 & .079 \\
\hline P3 & LM - Line management & 40 & 3.30 & 1.114 & .176 \\
\hline & Total & 290 & 3.45 & 1.146 & .067 \\
\hline & TM - Top management & 76 & 3.37 & 1.069 & .123 \\
\hline & SM - Middle management & 174 & 3.88 & 1.076 & .082 \\
\hline P4 & LM - Line management & 40 & 4.03 & .862 & .136 \\
\hline & Total & 290 & 3.77 & 1.072 & .063 \\
\hline & TM - Top management & 76 & 3.55 & 1.076 & .123 \\
\hline & SM - Middle management & 174 & 3.61 & .972 & .074 \\
\hline P5 & LM - Line management & 40 & 3.40 & .955 & .151 \\
\hline & Total & 290 & 3.57 & .997 & .059 \\
\hline & TM - Top management & 76 & 3.76 & 1.018 & .117 \\
\hline P6 & SM - Middle management & 174 & 3.84 & 1.099 & .083 \\
\hline Po & LM - Line management & 40 & 3.93 & 1.163 & .184 \\
\hline & Total & 290 & 3.83 & 1.085 & .064 \\
\hline & TM - Top management & 76 & 3.63 & 1.187 & .136 \\
\hline P7 & SM - Middle management & 174 & 3.71 & 1.052 & .080 \\
\hline P/ & LM - Line management & 40 & 4.30 & .464 & .073 \\
\hline & Total & 290 & 3.77 & 1.051 & .062 \\
\hline & TM - Top management & 76 & 3.95 & 1.057 & .121 \\
\hline P8 & SM - Middle management & 174 & 3.63 & .926 & .070 \\
\hline Pr & LM - Line management & 40 & 4.05 & .986 & .156 \\
\hline & Total & 290 & 3.77 & .983 & .058 \\
\hline & TM - Top management & 76 & 3.08 & 1.117 & .128 \\
\hline PQ & SM - Middle management & 174 & 3.55 & .953 & .072 \\
\hline 19 & LM - Line management & 40 & 3.15 & .949 & .150 \\
\hline & Total & 290 & 3.37 & 1.018 & .060 \\
\hline & TM - Top management & 76 & 3.74 & .755 & .087 \\
\hline D10 & SM - Middle management & 174 & 3.62 & .850 & .064 \\
\hline PIO & LM - Line management & 40 & 3.15 & 1.027 & .162 \\
\hline & Total & 290 & 3.59 & .869 & .051 \\
\hline
\end{tabular}

Source: Author

In table 2. ANOVA (Analysis of Variance) it was determined by a test the existence of differences in scores of competency of employees by managers who are in different managerial level. As the extent of the existence of significant differences taken the value 0.05 (for the value of SIG. $\leq 0.05$ a statistically significant difference in the scores). It is noticeable that the managers differently assessed competence P1 (Sig=0,009<0,05),P4 
( $\mathrm{Sig}=0,001<0,05), \mathrm{P} 7(\mathrm{Sig}=0,002<0,05), \mathrm{P} 8 \quad(\mathrm{Sig}=0,010<0,05), \mathrm{P} 9 \quad(\mathrm{Sig}=0,001<0,05)$, $\mathrm{P} 10$ ( $\mathrm{Sig}=0,002<0,05)$. From the observed ten variables significant difference in scores was observed in six, so that managers in the sample with different management levels differently value competence of employees.

Table 2: Differences in grades of competences of employed by different managers levels

\begin{tabular}{|c|c|c|c|c|c|c|}
\hline & & $\begin{array}{l}\text { Sum of } \\
\text { Squares }\end{array}$ & df & $\begin{array}{c}\text { Mean } \\
\text { Square }\end{array}$ & $\mathbf{F}$ & Sig. \\
\hline \multirow[t]{3}{*}{$\mathrm{P} 1$} & Between Groups & 10.985 & 2 & 5.492 & 4.839 & $.009 *$ \\
\hline & Within Groups & 325.760 & 287 & 1.135 & & \\
\hline & Total & 336.745 & 289 & & & \\
\hline \multirow[t]{3}{*}{$\mathrm{P} 2$} & Between Groups & 1.042 & 2 & .521 & .763 & .467 \\
\hline & Within Groups & 195.979 & 287 & .683 & & \\
\hline & Total & 197.021 & 289 & & & \\
\hline \multirow[t]{3}{*}{ P3 } & Between Groups & 7.059 & 2 & 3.529 & 2.718 & .068 \\
\hline & Within Groups & 372.666 & 287 & 1.298 & & \\
\hline & Total & 379.724 & 289 & & & \\
\hline \multirow[t]{3}{*}{$\mathrm{P} 4$} & Between Groups & 16.930 & 2 & 8.465 & 7.710 & $.001 *$ \\
\hline & Within Groups & 315.125 & 287 & 1.098 & & \\
\hline & Total & 332.055 & 289 & & & \\
\hline \multirow[t]{3}{*}{ P5 } & Between Groups & 1.440 & 2 & .720 & .723 & .486 \\
\hline & Within Groups & 285.815 & 287 & .996 & & \\
\hline & Total & 287.255 & 289 & & & \\
\hline \multirow[t]{3}{*}{ P6 } & Between Groups & .733 & 2 & .366 & .310 & .734 \\
\hline & Within Groups & 339.322 & 287 & 1.182 & & \\
\hline & Total & 340.055 & 289 & & & \\
\hline \multirow[t]{3}{*}{ P7 } & Between Groups & 13.263 & 2 & 6.631 & 6.225 & $.002 *$ \\
\hline & Within Groups & 305.716 & 287 & 1.065 & & \\
\hline & Total & 318.979 & 289 & & & \\
\hline \multirow[t]{3}{*}{ P8 } & Between Groups & 8.830 & 2 & 4.415 & 4.690 & $.010^{*}$ \\
\hline & Within Groups & 270.149 & 287 & .941 & & \\
\hline & Total & 278.979 & 289 & & & \\
\hline \multirow[t]{3}{*}{ P9 } & Between Groups & 14.119 & 2 & 7.059 & 7.092 & $.001 *$ \\
\hline & Within Groups & 285.661 & 287 & .995 & & \\
\hline & Total & 299.779 & 289 & & & \\
\hline \multirow[t]{3}{*}{ P10 } & Between Groups & 9.542 & 2 & 4.771 & 6.558 & $.002 *$ \\
\hline & Within Groups & 208.802 & 287 & .728 & & \\
\hline & Total & 218.345 & 289 & & & \\
\hline
\end{tabular}

Source: Author

In six of the ten observed variables it was noticed the significant difference in scores, and the subsequent Tukejev (Tukey) test found that managerial levels have made a significant difference in the scores. In the table 3. we can see that line/operational managers evaluated differently in comparison to top managers and middle management autonomy of employees in work and decision making (P1). The difference was observed by top managers in relation to the middle and line management/operational managers in the importance of energy with which employees access to performing work (P4). Line/ middle management valued differently from midlle and top management the interpersonal relations and communication with the colleagues that employees nourishes (P7). Middle management valued differently from the top management and line/operating management employees who know how to make a priority among tasks (P8). Top managers and middle 
management individually assessed plan and verification tasks before their execution (P9). Realising the benefits of its own ideas and projects, advocate it with valid argumnts in order for others to accept the proposition line managers/operating level manager valued diferently from the top management and middle management level (P10).

Table 3. The difference in managerial-level grades of employees competence

\begin{tabular}{|c|c|c|c|c|c|}
\hline \multirow{2}{*}{$\begin{array}{c}\text { Dependent } \\
\text { Variable }\end{array}$} & \multirow{2}{*}{$\begin{array}{c}\text { (I) } \\
\text { Management } \\
\text { level }\end{array}$} & \multirow{2}{*}{$\begin{array}{c}(\boldsymbol{J}) \\
\text { Management } \\
\text { level }\end{array}$} & $\begin{array}{c}\text { Mean } \\
\text { Difference (I-J) }\end{array}$ & $\begin{array}{l}\text { Std. } \\
\text { Error }\end{array}$ & Sig. \\
\hline & & & Lower Bound & $\begin{array}{l}\text { Upper } \\
\text { Bound }\end{array}$ & $\begin{array}{l}\text { Lower } \\
\text { Bound } \\
\end{array}$ \\
\hline \multirow{6}{*}{ P1 } & \multirow{2}{*}{$\mathrm{TM}$} & SM & -.197 & .146 & .372 \\
\hline & & LM & $-.646(*)$ & .208 & .006 \\
\hline & \multirow{2}{*}{ SM } & TM & .197 & .146 & .372 \\
\hline & & LM & $-.449(*)$ & .187 & .044 \\
\hline & \multirow{2}{*}{ LM } & TM & $.646\left(^{*}\right)$ & .208 & .006 \\
\hline & & SM & $.449(*)$ & .187 & .044 \\
\hline \multirow{6}{*}{ P4 } & \multirow{2}{*}{$\mathrm{TM}$} & SM & $-.511(*)$ & .144 & .001 \\
\hline & & LM & $-.657(*)$ & .205 & .004 \\
\hline & \multirow{2}{*}{ SM } & TM & $.511(*)$ & .144 & .001 \\
\hline & & LM & -.146 & .184 & .708 \\
\hline & \multirow{2}{*}{ LM } & $\mathrm{TM}$ & $.657(*)$ & .205 & .004 \\
\hline & & SM & .146 & .184 & .708 \\
\hline \multirow{6}{*}{ P7 } & \multirow{2}{*}{$\mathrm{TM}$} & SM & -.081 & .142 & .836 \\
\hline & & LM & $-.668(*)$ & .202 & .003 \\
\hline & \multirow{2}{*}{ SM } & TM & .081 & .142 & .836 \\
\hline & & LM & $-.587(*)$ & .181 & .004 \\
\hline & \multirow{2}{*}{ LM } & TM & $.668(*)$ & .202 & .003 \\
\hline & & SM & $.587(*)$ & .181 & .004 \\
\hline \multirow{6}{*}{ P8 } & \multirow{2}{*}{ TM } & SM & $.315(*)$ & .133 & .049 \\
\hline & & LM & -.103 & .190 & .851 \\
\hline & \multirow{2}{*}{$\mathrm{SM}$} & TM & $-.315(*)$ & .133 & .049 \\
\hline & & LM & $-.418(*)$ & .170 & .039 \\
\hline & \multirow{2}{*}{ LM } & TM & .103 & .190 & .851 \\
\hline & & SM & $.418\left(^{*}\right)$ & .170 & .039 \\
\hline \multirow{6}{*}{ P9 } & \multirow{2}{*}{$\mathrm{TM}$} & SM & $-.473(*)$ & .137 & .002 \\
\hline & & LM & -.071 & .195 & .929 \\
\hline & \multirow{2}{*}{$\mathrm{SM}$} & TM & $.473(*)$ & .137 & .002 \\
\hline & & LM & .402 & .175 & .058 \\
\hline & \multirow{2}{*}{ LM } & TM & .071 & .195 & .929 \\
\hline & & $\mathrm{SM}$ & -.402 & .175 & .058 \\
\hline \multirow{6}{*}{ P10 } & \multirow{2}{*}{$\mathrm{TM}$} & SM & .116 & .117 & .584 \\
\hline & & LM & $.587(*)$ & .167 & .001 \\
\hline & \multirow{2}{*}{$\mathrm{SM}$} & TM & -.116 & .117 & .584 \\
\hline & & LM & $.471(*)$ & .150 & .005 \\
\hline & \multirow{2}{*}{ LM } & TM & $-.587(*)$ & .167 & .001 \\
\hline & & SM & $-.471\left(^{*}\right)$ & .150 & .005 \\
\hline
\end{tabular}

Sources: Author

\section{Conslusion}

Often the question arises whether an organization needs to implement aproach based on competences? The answer varies depending on the approach that the 
oraginzation already adpted and how they are satisfied by it in terms of organizational benefits (Robertson, 1995). There are more and more discussion about employment based on competence, as well as lifelong learning that leads to achieving certain qualifications that are needed for certain jobs. A number of literature in the field of management has the tendency to focus on competences based on human resources (Kirton \& Healy, 2009).

By analysing the competences that managers evaluate as important, the results of the research showed that the managrs most value when an employee wants to learn something new, to improve knowledge and skills, does not resist to changes, has autonomy in work. After that three competences follow: energy at work, the importance of interpersonal relationships and job ranking by relevance, which are rated with the same average score. As the least significant competence it was rated: advocacy of their own ideas, employee's enthusiasm for their ideas and plans, addressing the focus of the documentation and recognition of procedures in task planning and review stages of the completion of a task. The results show that a group of competences relating to the execution of tasks and interpersonal relations managers price highly, while competence concidering documentation, ideas that employees want to implement managers prices less. The survey also showed that managers of different levels grade differently competences of employees given that in more than half of the observed competencies it was spotted the difference. Competences of employees are an essential factor of progress of an organization, they need to be set in accordance with the work performed by the employee, and each management level needs to determine what are the competence pertinent to the execution of individual tasks in the organization, and that accordingly works on developing employees.

\section{References}

Aksentijević, J.A., Avakumović, Č., Jelić, M. (2010). Competence and career development in manufacturing-business system info. The International Scientific ConferenceManagement, Zbornik, Krusevac: Faculty of industrial management, 39-45.

Bartol, M.K., Martin, C.D. (1994). Management. USA: McGraw-Hill.

Becker, G.S. (1983). Human Capital. Chicago: University of Chicago Press.

Bogićević B. (2004). Management of human resources. Belgrade: Faculty of Economics, Belgrade.

Deb, T. (2006). Strategic approach to human resource management. New Delhi: Atlantic Publishers and Distributors.

Department of Education, Science and Training (2002): Employability Skills for the Future, http://www.voced.edu.au/content/ngv\%3A12484

Gilbert, C., Winne, S. \& Sels, L. (2015). Strong HRM processes and line managers effective HRM implementation: a balanced view. Human Resource Management Journal, 25(4), 600-616.

Kermally, S. (2004). Gurus on Managing People. Lodnon: Thorogood.

Kirton, G., Healy, G. (2009): Using cometency-based assessment centres to select judges - implications for equality and diversity. Human Resource Management Journal, 19(3), 302-318. 
Krishnaveni, J. (2013). A study on mapping of employees`competency. Indian Journal of Economics and Development, 1(3), 71-75.

Marchington, M., Wilkinson, A. (2005). Human resource management at work. Londnon: Chartered Institute of Personnel and Development.

Micić, R. (2015). Leadership role in certain phases of knowledge management processes. Ekonomika 61(4), 47-56.

Nelson, B., Economy, P. (2005). The Management Bible. USA: John Wiley \& Sons.

Praštalo, R. (2010). Kompetencije i karijera. Ljubljana: Narodna in univerzitetna knjižnica.

Robertson, C (1995). NVQs: the impact of competence approaches. Management Development Review, 8 (6), $23-27$.

Robotham, D., Jubb, R. (1996). Competences: measuring the unmeasurable. Management Development Review, 9 (5), 25 - 29.

Rubin, N.J., Leigh, I.W. Nelson, P.D., Smith, I.L., Bebeau, M., Lichtenberg, J.W. Portnoy, S., \& Kaslow, N.J. (2007). The competency movement within psychology: An historical perspective. Professional Psychology: Research and Practice, 38(5), 17-34.

Sanchez, J. I., \& Levine, E. L. (2009). What is (or should be) the difference between competency modeling and traditional job analysis? Human Resource Management Review, 19(2), 53-63.

Sanders, K., Yang, H. (2016): The HRM Process Approach: The Influence of Employees 'Attribution to Explain the HRM-Performance Relationship. Human resource management, 55(2), 201-217.

Seate, B., Pooe, R. \& Chinomona, R. (2016). The relative importance of managerial competencies for predicting the perceived job performance of Broad-Based Black Economic Empowerment verification practitioners. SA Journal of Human Resource Management/SA Tydskrif vir Menslikehulpbronbestuur, 14(1), a696. http://dx.doi. org/10.4102/sajhrm. v14i1.696.

Stojković, A., Davidovac, Z., Stojmirović, B. (2014): The impact of motivation on business success. Economics,54(1) $174-181$.

Šušnjar, G., Zimanji V. (2006). Human resource management, Project: Faculty of Economics, University of Novi Sad.

Vujić, D. (2015). Competences - answer to new challenges of human resources management, The second international scientific conference "Synthesis", 16-17 April, University Singidunum, Belgrade. 